IJLR: International Journal of Law Recontruction

Volume 5, Number 2, September 2021

DOI : http://dx.doi.org/10.26532/ijlr.v5i2.12668

\title{
THE POSITION OF DAUGHTERS IN BALINESE CUSTOMARY INHERITANCE SYSTEM FROM GENDER EQUALITY PERSPECTIVE
}

\author{
Ni Made Sumerti Asih \\ Akademi Pariwisata Denpasar \\ sumertiasih58@gmail.com \\ Made Emy Andayani Citra \\ Mahasaraswati University Denpasar \\ emyandayanifh@gmail.com
}

\begin{abstract}
The purpose of this research on the position of daughters in Balinese customary inheritance system from gender equality perspective is to analyze the inheritance system according to Balinese customary law and to find the struggle for gender equality through the position of women as heirs. This research is a normative juridical study that examines the provisions of Balinese customary law, various court decisions and studies of international legal instruments regarding gender equality in inheritance for women. Basically, Balinese indigenous people adhere to a patrilineal kinship system. As a consequence, the line is drawn from the father and heirs are only boys, while girls can only enjoy the assets of their parents as long as they are not married. This condition certainly reduces women's access to economic rights. Whereas economic control is very important in living life. The equality of men and women in the inheritance system is a concern in the development of Balinese customary law. Decree of the Pesamuhan Agung Majelis Utama Pakraman Village, Bali No. 01/KEP/PSM-3/MDP Bali/X/2010, dated 15 October 2010 provides opportunities for girls to become heirs with limited provisions. Even so, the position of women as heirs in Balinese customary law is still difficult to implement because it is considered to be contrary to customary law in many places in Bali. This is due to a strong patriarchal culture that places men in higher power relations.
\end{abstract}

Keywords: Daughter; Heirs; Gender; Equality.

\section{A. INTRODUCTION}

Inheritance according to customary law of inheritance is a process of transferring assets both in the form of material objects and immaterial objects from a generation (the decedent who inherits) to the next generation (heirs). ${ }^{1}$ The inheritance customary law in Indonesia shows its distinctive character because it is based on principles arising from ideologies in a magical-religious, communal, concrete and constant society. Inheritance customary law has a different character according to the marriage system adopted by the community. The difference in customary

1 Bushar Muhammad, Pokok-Pokok Hukum Adat, Pradnya Paramitha, Jakarta, 2002, page. 3 
inheritance is that there are inheritance that can be divided and assets that cannot be divided or postponed for a long time.

In the customary law of inheritance in Bali, there is a difference in the system, in which only sons who have the inheritance rights. The daughter can only be heirs if she is given the status of purusa (sentana rajeg), in which the man who becomes her husband, will enter the family tree of his wife. Girls who have married, give up their rights in their original family. While even in the husband's family, she is not the heir. Boys born in rich families are very lucky because they become heirs of their fathers, while the fate of girls depends on the economic conditions of their husbands. This condition certainly shows gender inequality between men and women.

The patriarchal (purusa) kinship system adhered by the Hindu community in Bali causes only descendants who have the status of purusa who are considered to be able to guarantee and continue family responsibilities in relation to the implementation of religious ceremonies. They are responsible as members of society and responsible for parents, extended family and heirlooms. The consequence is that only the descendants with the status of purusa have the right to be heirs, while the female descendants are considered unlikely to be able to carry on the responsibility. Girls are equated with people who leave family responsibilities (ninggal kedaton). With these considerations, women are deemed not entitled to inheritance from the family.

In a family, the father is the head of the family who is obliged to earn a living as well as the owner of the family assets that are inherited from generation to generation from his parents. Before marriage, the daughter is the responsibility of her father. After marriage, she is the property and responsibility of the husband. As "property", whatever she owns is her father's and becomes his husband's when she is married. When it is connected to the kinship system adopted by the Hindu community in Bali, namely the patrilineal system, only boys have the right to inherit while girls are not entitled to inherit. The provisions of Balinese customary law that do not give girls to inherit the inheritance of their parents are in accordance with the provisions of the kinship system adhered and do not conflict with the applicable customary law. ${ }^{2}$

Women in Bali can only enjoy the inheritance of their husbands and parents. However, they cannot own them. In the social structure of society in Bali, men are indeed more dominant than women. This male-dominated legal system places women in a subordinate position. ${ }^{3}$ It is a gender inequality in the inheritance system. Andrew Morrison, Dhushyanth Raju, and Nistha Sinha state "In patrilineal systems, women obtain usufruct rights from their husbands. These rights, however, are typically lost upon divorce, widowhood, or physical relocation. Even in matrilineal systems, where inheritance is through the mother's line, land is owned and controlled by

2 Ni Luh Gede Isa Praresti Dangin, Kedudukan Hak Mewaris Wanita Hindu dalam Sistem Hukum Adat Waris di Bali, Kumpulan Jurnal Mahasiswa Fakultas Hukum, 2015, page. 19-20

3 A. Muktie Fadjar, Teori-teori Hukum Kontemporer, Setara, Malang, 2013, page. 81. 
men. ${ }^{\prime 4}$ Gender inequality in land ownership is related to male preference in inheritance, male privilege in marriage, male bias in community. ${ }^{5}$

In the modern life nowadays, people's views have begun to shift and there is an increasing demand for gender equality, in which family property does not only belong to the father but also to the mother. This is inseparable from the fact that in society a girl or a wife/mother can carry out her responsibilities to earn a living in order to support her family. Balinese women are supposed to get the same attention as men, because during life the female parents also carry out their duties such as caring for their parents during their lifetime, so they deserve to be considered as heirs. ${ }^{6}$ In fact, a woman can leave an inheritance because during her lifetime, she works.

Decree of the Grand Assembly of the Pakraman Village, Bali No. 01/KEP/PSM-3/MDP Bali/X/2010, dated October 15, 2010, is a revolutionary decision of traditional leaders in Bali who legitimized the granting of inheritance rights to girls even though within certain limitations. Unfortunately, in terms of inheritance, women are not yet fully recognized as heirs. The loss of women's access as heirs will reduce women's economic rights, even though these rights are very much needed to determine women's bargaining position in the family and in their social life.

Academically, this injustice rooted in the relationship between men and women is commonly referred to as gender inequalities. It is a shame that the visionary thoughts that appear in various discussions remain as ideas that have never been manifested in any legal product. Subsequent Court decisions regarding inheritance disputes still place women in a very weak position in inheritance, especially for girls who have already married outside. Balinese customary law still places women as limited and conditional heirs. $^{7}$

Research on the inheritance rights of girls in Balinese customary law has been written by several researchers. Ni Ketut Sari Adnyani and I Gusti Ayu Purnamawati conducted a research on "Mainstreaming the Gender of Female Citizen in Balinese Customary Law." The results of the study show that the problem is related to the guarantee of state legal protection for citizens, namely Balinese women regarding the legal consequences of divorce from mixed marriages. ${ }^{8}$

Desyanti Suka Asih K. Tus conducted a research on "The right of Balinese Hindu women to inheritance of husbands." The results of this study

4 Andrew Morrison, Dhushyanth Raju, and Nistha Sinha, Gender equality, poverty and economic growth, The World Bank, 2007, page. 19.

5 Carmen Diana Deere, and Magdalena León, The gender asset gap: Land in Latin America, World development, Volume 31, No. 6, 2003, page. 925-947, page. 925.

6 I. Gede Putra Manu Harum, and AA Gede Agung Dharma Kusuma, Kedudukan Ahli Waris Perempuan Bali dalam Perspektif Hukum Waris di Indonesia, Kertha Semaya: Journal IImu Hukum, Volume 1, No. 1, 2013. page. 3.

7 I Ketut Sudantra and I Gusti Ngurah Dharma Laksana, Pengaruh Ideologi Gender Terhadap Perkembangan Hak Waris Perempuan Bali, Volume 5, No. 4, 2016, page. 829.

8 Adnyani, Ni Ketut Sari, and I. Gusti Ayu Purnamawati, Pengarusutamaan Gender Krama Istri (Warga Perempuan) dalam Hukum Adat Bali, Pandecta Research Law Journal, Volume 15, No. 1 , 2020, page. 26-43. 
state that social changes and demands of feminist theory have not brought changes to the application of Balinese traditional inheritance law in society. There are provisions in the form of the MUDP (Indonesian Government Agency for Balinese) decision and the Supreme Court decision that has not been able to change the position of women (widows due to death) as husband's heirs. The lack of knowledge and legal awareness of Hindu women in Bali regarding their position as heirs is one of the reasons for the weak position of Hindu women in Bali as heirs. ${ }^{9}$

I Nyoman Suadnyana \& Made Novita Dwi Lestari wrote about "Bali's customary inheritance law as reviewed by the Supreme Court Decision No. 179/K/1961/23/10/1961." The patrilineal system entitles sons to inherit (purusa). If there are boys and girls, girls are not entitled to inherit the assets of their parents. It can be seen that the position of girls in inheritance rights is so weak according to the Balinese customary law system, that it is necessary to make changes that pay more attention to women's rights. ${ }^{10}$

This research is different from previous studies. This research will describe the inheritance rights for women in Bali according to Balinese customary law, the tendency of women to obtain inheritance rights and the struggle for gender equality through the position of women as heirs. The struggle for gender equality is analyzed from various legal and human rights instruments, as well as court decisions that provide opportunities for women as heirs.

\section{B. RESEARCH METHODS}

The research on the position of daughters in Balinese customary inheritance system from gender equality perspective is a normative juridical research. The study was carried out on Balinese customary law, Hindu law, legal instruments and court decisions regarding the position of girls as heirs in Balinese customary law. The problem approach is carried out systematically, evaluative and argumentative. The legal materials used consisted of primary legal materials, namely Pesamuhan Agung, the Main Assembly of Pakraman Village, Bali No. 01/KEP/PSM-3/MDP Bali/X/2010, dated 15 October 2010, Supreme Court decision No. 4766/Pdt/1998, dated 11 June 1999 and so on. Secondary legal material consists of various literatures that are relevant to this issue. Legal materials were collected through literature study. The problem analysis is done qualitatively.

\section{RESULT AND DISCUSSION}

\section{The Inheritance System According to Balinese Customary Law}

Inheritance customary law is a set of normative rules governing the process of transferring assets from a generation (the decedents who

9 Tus, Desyanti Suka Asih K, Hak Perempuan Hindu Bali Atas Harta Warisan Suami, Vyavahara Duta, Volume 16, No. 1, 2021, page. 68-79.

10 Suadnyana, I. Nyoman, and Made Novita Dwi Lestari, Hukum Waris Adat Bali Yang Ditinjau Dari Putusan Mahkamah Agung Nomor 179/K/1961/23/10/1961, Pariksa, Volume 1, No.1, 2020, page. 1. 
inherit) to their heirs. The inheritance customary law contains norms, subjects and objects of inheritance law, as well as the process of transferring property. The norms govern the process of transferring property from the decedent) to the heirs that contains their rights and obligations. The subject of inheritance law is a person who inherits property (decedent) and a group of people who receive an inheritance (heir). There are two subjects of inheritance, namely: the person who passes a No. of assets to their heirs, and the heir, namely the children and grandchildren who are entitled to receive the property, as well as having the obligation to pass on to the following heirs. Both the decedent and the heir are bound by a binding rule and the bond originates from blood or hereditary ties.

The object of inheritance is a No. of tangible and intangible assets. Inheritance is something that is inherited either in the form of tangible or intangible objects. In a narrow sense, inheritance is defined as items in the form of property left by the decedent. In Balinese customary law, inheritance is not only in the form of tangible goods but also intangible goods, namely community rights, including: the right to family property, the right to Karang Desa (village land) attached to one's status as a member of the community, the right to use Setra Desa (village graves) and the right to pray in Prahyangan Desa (tempels in the village) and others.

In the law of inheritance, there is also a process of transferring a No. of assets, in which this process is done both before and after the decedent dies. Customary inheritance law contains rules for seeing and determining heirs. This law recognizes three inheritance systems, namely:

a. Individual Inheritance System, which is an inheritance system determing that heirs inherit individually, for example in Java, Batak, Sulawesi, and others.

b. Collective Inheritance System, which is a system determining that the heirs inherit the inheritance collectively because it cannot be divided into individual heirs, for example "harta pusaka" in Minangkabau and "tanah datr" in the Hitu Ambon peninsula.

c. Majorate Inheritance System, which is an inheritance system determining that the inheritance of the decedent is only inherited by a child. There are two types of majorate systems, namely:

1) Male majorate, that is, if the eldest/eldest son or male descendant is the sole heir of the decedent, for example in Lampung.

2) Female majorate, that is, if the oldest daughter is the sole heir of the decedent, for example in the Tanah Semendo community in South Sumatra. ${ }^{11}$

Customary inheritance law regarding several principles, namely the

11 Ahlan Sjarif, Surini dan Nurul Elmiyah, Hukum Kewarisan BW "Pewarisan Menurut UndangUndang, Badan Penerbit Fakultas Hukum Universitas Indonesia, Depok, 2005, page. 13. 
principle of indivisibility and the principle of changing places. The general principle is that if the inheritance cannot be carried out from a generation to generation, then it is carried out upward or sideways. It means that firstly, the heirs are the sons or daughters and their offspring. If there are no children or hereditary descendants, then it falls on the father, grandmother and so on. If this also does not exist, it is the relatives of the deceased who inherit the property and their descendants, namely blood relatives according to the sideline, on the understanding that the closest relatives exclude families who are far away. The principle of changing place (Plaats Vervulling) which states that if a child is the heir of his father, and he dies, his place is replaced by his children (grandchildren of the decedent). And the inheritance for this grandchildren is the same as what his father will get as part of the inheritance received. It is known that there is an agency for adoption, in which the rights and positions can also be same like their own (biological) children. ${ }^{12}$

Customary inheritance law is basically guided by the kinship system

in Indonesia. The traditional inheritance kinship system can be distinguished into three features, namely:

a. The Patrilineal system, which is a family system that draws the lineage of the male ancestors. In this system, the position and influence of men in inheritance law is very prominent. For example in the Batak community, only boys are heirs because a married girl is considered as a family member of her husband's family, then she is not the heir of her parents who have passed away. Another example of the patrilineal system is in the communities of Pacitan, Bali, Gayo, Alas, Nias, Lampung, Buru, Seram, Nusa Tenggara and Irian.

b. The Matrilineal system, which is a family system that draws the lineage of the female ancestors. In this system, men do not inherit their children, because their children are part of the mother's family, while the father is still a member of his own family. The examples in the community: Minangkabau, Enggano and Timor.

c. Parental or Bilateral System, namely a hereditary/kinship system that draws lineages from two sides, namely from the father and the mother. In this system, the position of boys and girls in the law of inheritance is equal, meaning that both boys and girls in the law of inheritance are the same and equal, meaning that both boys and girls are heirs of the assets, legacy of their parents. The examples include the people of Java in general, Aceh, East Sumatra, Riau, Kalimantan, Sulawesi and others. ${ }^{13}$

Balinese traditional law of inheritance cannot be separated from family law, especially the kinship system adopted in general. It is also cannot be separated from the form of marriage adopted by the customary law community in Bali, because inheritance issues are largely determined by the kinship system in the effect and the form of marriage

12 Datuk Usman, Hukum Adat II, Fakultas Hukum Sumatra Utara, Medan, 1992, page. 192.

13 Eman Suparman, Intisari Hukum Waris Indonesia, Armico, Bandung, 1985, page. 49. 
that is carried out by the Balinese people. These two things are closely related. Balinese people who are Hinduism adhere to the patrilineal kinship system. ${ }^{14}$

In the inheritance system in Bali, the principles of kinship to purusa are the same as the kinship system adopted in the Manawa Dharmasastra holy book known as one of the Hindu Law books (Windya, 2006). The purusa system (patrilineal) adopted by the Balinese people has an effect on leadership patterns, social life arrangements, culture, customs, welfare fulfilment systems that cover traditional village communities in every traditional village in the province of Bali. ${ }^{15}$ Inheritance in Balinese customary law is related to the rights and obligations of the heir.

Inheritance according to Balinese customary law can be in the form of heirlooms. The heirlooms are assets that have religious magical value and are not normally distributed. The process of the inheritance is maintained in the family environment as a whole and from generation to generation and must in the family environment. These inheritance assets in Bali are generally related to places of worship, so that their integrity is maintained for religious purposes and not other interests. This is because the majority of Balinese people adhere to Hinduism. The types of inheritance in Bali are sanggah (temple or place of worship in the house), keris pengentas (holy traditional Balinese sword), ceremonial tools, devotional land, temple's profits and druwe tengah (temple's property). Tetamian or heirloom that cannot be shared are assets that have religious magical value, such as a place for family prayer or merajan, keris pengentas, and temple's profits. Heirloom or tetamian that can be divided are inheritance assets that do not have religious value, such as rice fields, fields and others. The obligation to worship ancestors and care for heirlooms in the patrilineal kinship system can only be done by male descendants. This is the basis for the idea that the heir in Bali is a boy.

During its development, there are girls who have married, but within certain limits, it is still possible to carry out their responsibilities as Hindus in their original family. This condition is called ninggal kedaton terbatas. There are also women who leave their original family that it is no longer possible for them to carry out their responsibilities as Hindus or ninggal kedaton penuh, and they can be categorized as not having the right to inheritance at all, while those who are still responsible for the family of origin are still limited to obtain inheritance based on the principle: ategen asuun (a tradisional system of inheritance division in which the boy gets $2 / 3$ of the property and the rest is for the girl). Even so, the conditions under which Balinese women can become heirs are still

14 Sukerti, Hak Mewaris Perempuan Dalam Hukum Adat Bali Sebuah Studi Kritis, Udayana University Press, Denpasar, 2012, page. 55.

15 Ni Ketut Sari Adnyani, and I. Gusti Ayu Purnamawati, Pengarusutamaan Gender Krama Istri (Warga Perempuan) dalam Hukum Adat Bali, Pandecta: Jurnal Penelitian IImu Hukum (Research Law Journal), Volume 15 No. 1, 2020, page. 26-43, 27. 
far from expectations.

The importance of equality between men and women is actually a mandate contained in the Convention on the Elimination of All Forms of Discrimination against Women (CEDAW). This provision has been ratified through Law of the Republic of Indonesia No. 7 of 1984 concerning Ratification of the Convention on the Elimination of All Forms of Discrimination against Women. Laws promoting gender equality often fail to improve women's experiences. This failure is particularly acute for the experiences of socio-economically marginalized women. The understanding why legislated equality as prescribed in laws often does not lead to the equality of outcomes is an ongoing puzzle in the studies of gender and politics. ${ }^{16}$

\section{The Struggle for Gender Equality Through The Position of Women as Heirs}

Gender equality which refers to equality between men and women is a human right that is respected by the world. In the Universal Declaration of Human Rights, it is stated: "Whereas the peoples of the United Nations have in the Charter reaffirmed their faith in fundamental human rights, in the dignity and worth of the human person and in the equal rights of men and women and have determined to promote social progress and better standards of life in larger freedom." The struggle for women's equality has been carried out in every period of life. Gender relations and roles are not the phenomenon that change overnight. Rather, gender inequality has historical roots. ${ }^{17}$

From a historical perspective, the movement of women to fight for their rights has started since the $19^{\text {th }}$ century in the United States. First, during the $19^{\text {th }}$ century attempts were made to gain the right to vote, gain access to private property in marriage and to laws to control births. The second movement began in the 1960s when a large No. of women entered legal education and practice. The third movement took place in 1970. The focus was on work, family law and the legal definition of rape. The fourth movement, which began presumably in the late 1980s and lasted until the late 1990s saw a No. of setbacks in its early stages (e.g. the defeat of the equal rights amendment on restrictions imposed on abortion rights). However, in the 1990s, a new impetus was informed by critical findings in other fields; political theory, literary criticism, and psychoanalytic philosophy emerged. ${ }^{18}$

Customary inheritance law cannot be separated from the kinship system adhered by indigenous peoples. The kinship system adopted by

16 Salih Yasun, Does education enable underprivileged women to achieve real equality in property rights? A case study of inheritance rights of women in Turkey, Women's Studies International Forum, Volume 69, No. 1, 2018, page. 100.

17 Sarah Carmichael, Selin Dili and Auke Rijpma, Gender inequality since 1820, in Jan Luiten van Zanden, et al. (eds.), How Was Life?: Global Well-being since 1820, OECD Publishing, 2014, page. 217-248, 218.

18 Otje Salman dan Anthon F. Susanto, Teori Hukum, Refika Aditama, Bandung, 2004, page. 131-132. 
the Hindu community in Bali is a patrilineal kinship system. The patrilineal kinship system has a transcendental view that the line of life of the descendants is drawn from the line with the legal status of the purusha. The status of purusha is generally male, except in the case of girls having the status of purusha. For Balinese indigenous people who have the right to inherit are only those with legal status of purusha as descendants with the obligation to worship at the ancestral temple (kawitan). Patrilineal legal society is a legal society, in which the members draw the lineage upward through the father's line, the father from the father continues upward, so that one man is found as his ancestor. ${ }^{19}$ Injustice towards women in the inheritance system in Bali is influenced by the patriarchal culture adhered by Balinese society. This culture places men and women in unequal power relations. Patricia Smith mentions:

Patriarchy is the systematic subordination of women to men, and that is the experience that all women share. The point of view of all women is the point of view of those who are subordinated on the basis of their sex regardless of what else may be different about them. Even if some individual personal relationships deviate from this norm, systematic social organization still conforms to it everywhere. ${ }^{20}$

The condition of gender inequality in Bali which places women in a subordinate position is contrary to the teachings of Hinduism adhered by the Balinese people. In Manawadharmasastra Chapter III Sloka 56 which reads "Yatra naryastu pujyante, Ramante tatra dewata, Yatraitastu na pujiante, Sarwastalah kriyah" (where women are honored, that's where the gods are happy, but where they are not respected, no sacred ceremony is rewarding). Furthermore, in Sloka 133 it is mentioned "Pautra daushitrayor loke, Na wiceso'sti dharmatah, Tayorhi mata pitarau, Sambhutau tasya dehitah" (There is no difference between sons and daughters (women) who are promoted to status, whether related to worldly matters or matters of sacred obligations because for their father and mother, both were born from the same body of the person).

Efforts in providing justice for women to obtain an inheritance and to become the heir cannot be separated from the social changes occurred in society. Currently, women are not only housewives in the family, but also work to help the family's economy, and sometimes even become the backbone of the family buying assets. In this condition, it is unfair if when the husband dies, a woman is only entitled to enjoy the assets owned in the marriage and this right can also be lost when the widow remarries. A widow who remarries must leave her belongings, including during marriage and return it to the family of the deceased husband.

19 IGN Sugangga, Hukum Adat Waris Pada Masyarakat Hukum Adat yang Bersistem Patrilineal di Indonesia, Semarang, 1988, page. 14.

20 Patricia Smith dalam Dennis Patterson (ed.), A Companion to Philosophy of Law and Legal Theory Second edition, West Sussex: Blackwell, 2010, page. 294. 
Married girls often carry out obligations towards their original family, namely in terms of worshiping their ancestors and in caring for their parents. In Balinese life today, many parents have been found living with their married daughters. This social change needs to be responded to with equal rights for girls to become heirs to their parents, even though the girl is not a purusha in her original family. I Gede Putra Manu Harum and A.A. Gede Agung Dharma Kusuma state "Balinese women should receive the same attention as men, because during their parents' lifetime, they also perform their duties such as caring for their parents, so they deserve to be counted as heirs." 21

Efforts to place women as heirs are carried out through inheritance suits in court. In the Supreme Court decision No. 4766 /Pdt/1998, dated 11 June 1999, the Court has decided that the Balinese daughters may also be a descendant and hold inheritance rights to inherit the property of their father. The Court has started aware to the position of the woman within the life of the traditional community which shall be improved in a proper way. So, they may own rights for inheriting including in the patriarchal system where women mostly ignored by the system. Under its decision, the Court has started granting rights for inheriting to the women even though they live within a society which prevail patriarchal system. The women shall be positioned as equal as men do in the case of inheriting. 22

Before 2010, the basis of inheritance was Peswara 1900 and traditional rules or awig-awig which both placed sons as heirs, however in Peswara and awig-awig it was also determined that sentana rajeg and adopted children had the status of heirs, while daughters were not declared heirs. The Balinese traditional inheritance system does not place women as absolute heirs, like boys. For Balinese girls, the status is as heirs if they are only children who are designated as sons (sentana rajeg). The daughter who has the status of purusa continues her father's property as heir to her parents' property. It is possible for women in Bali to become heirs if they have the status of sentana rajeg. According to Artadi, sentana rajeg is the name of a form of marriage in Balinese customary law, in which the woman marries the man by drawing him to her family, and the consequence is that the woman is the purusa and the man is the pradana. ${ }^{23}$ In the Manawa Dharmasastra Book (IX: 127), sentana rajeg is called a putrika which has the same position as a son, namely as a continuation of the descendants and heirs of his parents' assets.

Since 2010 based on the Decree of Pesamuhan Agung, the Main

21 I Gede Putra Manu Harum dan A.A. Gede Agung Dharma Kusuma, Kedudukan Ahli Waris Perempuan dalam Persfektif Hukum Waris Indonesia, Bagian Hukum Perdata FH-UNUD, 2018, page. 3 .

22 Hanna Christine Ndun, Sarah Suttor, and I. Gusti Agung Ayu Dike Widhiyaastuti. Does Customary Law Discriminate Balinese Women's Inheritance Rights?, Udayana Journal of Law and Culture, Volume 2, No. 1, 2018, page. 104.

23 I Ketut Artadi, Hukum Adat Bali Dengan Aneka Masalahnya, Pustaka Bali Post, Denpasar, 2003, page. 28. 
Assembly of Pakraman Village, Bali No. 01/KEP/PSM-3/MDP Bali/X/2010, on October 15, 2010, it has decided: it is possible for girls/women as heirs to be limited to inheritance for their parents' wealth on the principle of ategen asuun (2: 1) after deducting $1 / 3$ for the duwe tengah (joint property), this also applies to men who marry intermarry (nyeburin). Decree of the Pesamuhan Agung Main Assembly of Pakraman Village, Bali No. 01/KEP/PSM-3/MDP Bali/X/2010, dated 15 October 2010 as follows:

a. Husbands and wives as well as their children and their brothers have the same position in welfare, to ensure that the inheritance can be passed on to their children and grandchildren and preserve the immaterial inheritance;

b. During their marriage, husband and wife have the same position towards harta guna karya (assets obtained during their marital status).

c. Natural children (boys/girls) as well as adopted children (boys/girls) basically have the same position as the inheritance for their parents' wealth.

d. Biological children (boys/girls) and adopted children (boys/girls) have the right to the wealth of their parents after deducting $1 / 3$ as duwe tengah (joint property) not to be owned by children who are nguwubang (continuing swadharma/responsibility of their parents).

e. Children with purusa status are entitled to I part of the inheritance property, while those with status pradana/ninggal kedaton terbatas are entitled to a half of the inheritance property received by a child with the status of a purusa.

f. In terms of distribution of inheritance, a child who is still in the womb has the same rights as a child who has been born as long as he is born alive.

g. Children who are ninggal kedaton penuh are not entitled to inheritance property, but their parents can give them provisions (life of funds or jiwa dana) from their assets without harming the heirs.

Decree of the Pesamuhan Agung Majelis Utama Pakraman Village, Bali No. 01/KEP/PSM-3/MDP Bali/X/2010, dated October 15, 2010, granting inheritance rights for girls who are ninggal kedaton terbatas. Those who are ninggal kedaton terbatas may get an inheritance based on the principle of ategen asuwun (2:1), with their relatives having the status of purusa. Ninggal kedaton terbatas is ninggal kedaton but within certain limits, it is still possible to carry out swadharma (obligation) as a Hindu. ${ }^{24}$ Based on this decree, ninggal kedaton terbatas are as follows:

a. Women who are in the ordinary marriages.

b. Men who are marrying nyentanal nyeburin.

c. Those who have been adopted as children (kaperas sentana) by another family in accordance with Hinduism and Balinese customary

24 Wayan P. Windia, Ni Made Wiasti dan Ni Luh Arjani, Pewarisan Perempuan Menurut Hukum Adat di Bali, Udayana University Press, Denpasar, 2012, page. 80. 
law.

d. Submit/surrender oneself (makidihang raga) to another family of their own will.

Daughters are only entitled to inheritance from their parents as long as they have not yet married, which is $2: 1$, namely 2 for boys and 1 for girls. If they are married, they cannot bring it into the marriage. By deciding the position of women in inheritance according to Balinese customs, the Traditional Village Council is obliged to conduct socialization to the Balinese people so that the traditional village stipulates it in the customary awig-awig (rules) in Bali. Decree of the Grand Assembly of the Pakraman Village, Bali No. 01/KEP/PSM-3/MDP Bali/X/2010, dated 15 October 2010 is seen as very progressive as a way of equality in position for Balinese women today, in terms of their rights and obligations.

The struggle for gender equality in obtaining economic rights through inheritance rights for girls in Bali is normatively progressing. In practical terms, the inheritance rights for girls have not been fully accepted by the indigenous people in Bali. Provisions regarding the inheritance rights of girls have not been regulated in awig-awig (customary village regulations). The legal culture of men in Balinese society also has not fully accepted the existence of women as heirs. As a result, although the Decree of the Grand Assembly of the Pakraman Village, Bali No. 01/KEP/PSM-3/MDP Bali/X/2010 has provided opportunities for girls to inherit, but the distribution of inheritance for girls cannot be implemented.

\section{CONCLUSION}

The inheritance system according to Balinese customary law basically places men as heirs. The position of women in inheritance according to Balinese customary law is not absolute compared to the position of boys as heirs. This is inseparable from the patrilineal (purusa) system adhered by the Balinese, which places only offspring with the status of purusa who are entitled to family inheritance except for a single daughter who has the status of sentane rajeg. The struggle for gender equality through the position of women as heirs is carried out through a human rights approach. The implication, at the normative level, is that there is a shift in the patrilineal concept of inheritance according to Balinese customary law towards a parental concept. Women have been positioned as heirs since it was decided in the Decree of Pesamuhan Agung III No.1/Kep/Psm-3/MUDP Bali/2010 dated 15 October 2010, in which Balinese girls are included as limited heirs of the inheritance for their parents' wealth on the principle of: ategen asuun (2: 1) after deducting $1 / 3$ for the duwe tengah (joint property). However, the implementation of these provisions has not been fully implemented by the indigenous peoples in Bali. The grant of inheritance rights for girls can be done if the men in the family concerned provide the opportunity for the girls or sisters to get a share of assets that can be divided. Nonetheless, the legal changes that would allow for 
daughters as heirs can not be enforced consistently because it is contrary to customary laws in each village in Bali.

\section{Books:}

\section{BIBLIOGRAPHY}

A. Muktie Fadjar, 2013, Teori-teori Hukum Kontemporer, Setara, Malang;

Ahlan Sjarif, Surini dan Nurul Elmiyah, Hukum Kewarisan BW "Pewarisan Menurut Undang-Undang (Depok : Badan Penerbit Fakultas Hukum Universitas Indonesia, 2005).

Andrew Morrison, Dhushyanth Raju, and Nistha Sinha 2007, Gender equality, poverty and economic growth, The World Bank;

Bushar Muhammad, 2002, Pokok-Pokok Hukum Adat, Pradnya Paramitha Jakarta;

Datuk Usman, 1992, Hukum Adat II, Fakultas Hukum Sumatra Utara, Medan;

Eman Suparman, Intisari Hukum Waris Indonesia, 1985, Armico, Bandung;

I Gede Putra Manu Harum dan A.A. Gede Agung Dharma Kusuma, 2018, Kedudukan Ahli Waris Perempuan dalam Persfektif Hukum Waris Indonesia, Bagian Hukum Perdata FH-UNUD, Denpasar;

I Ketut Artadi, 2003, Hukum Adat Bali Dengan Aneka Masalahnya, Pustaka Bali Post, Denpasar;

IGN Sugangga, 1988, Hukum Adat Waris Pada Masyarakat Hukum Adat yang Bersistem Patrilineal di Indonesia, Semarang;

Otje Salman dan Anthon F. Susanto, 2004, Teori Hukum, Refika Aditama, Bandung;

Patricia Smith dalam Dennis Patterson (ed.), 2010, A Companion to Philosophy of Law and Legal Theory Second edition, West Sussex: Blackwell;

Sarah Carmichael, Selin Dili and Auke Rijpma, 2014, Gender inequality since 1820, in Jan Luiten van Zanden, et al. (eds.), How Was Life?: Global Well-being since 1820, OECD Publishing;

Sukerti, 2012, Hak Mewaris Perempuan Dalam Hukum Adat Bali Sebuah Studi Kritis, Udayana University Press, Denpasar;

Wayan P. Windia, 2012, Ni Made Wiasti dan Ni Luh Arjani, Pewarisan Perempuan Menurut Hukum Adat di Bali, Udayana University Press, Denpasar.

\section{Journals:}

Carmen Diana Deere, and Magdalena León, The gender asset gap: Land in Latin America, World development, Volume 31, No. 6, 2003;

Hanna Christine Ndun, Sarah Suttor, and I. Gusti Agung Ayu Dike Widhiyaastuti. Does Customary Law Discriminate Balinese 
Women's Inheritance Rights?'. Udayana Journal of Law and Culture Volume 2, No. 1, 2018;

I Gede Putra Manu Harum, and AA Gede Agung Dharma Kusuma, Kedudukan Ahli Waris Perempuan Bali dalam Perspektif Hukum Waris di Indonesia, Kertha Semaya: Journal Ilmu Hukum, Volume 1, No. 1, 2013;

I Ketut Sudantra and I Gusti Ngurah Dharma Laksana, Pengaruh Ideologi Gender Terhadap Perkembangan Hak Waris Perempuan Bali, Volume 5, No. 4, 2016;

Ni Ketut Sari Adnyani, and I. Gusti Ayu Purnamawati, Pengarusutamaan Gender Krama Istri (Warga Perempuan) dalam Hukum Adat Bali, Pandecta: Jurnal Penelitian IImu Hukum (Research Law Journal), Volume 15 No. 1, 2020;

Salih Yasun, Does education enable underprivileged women to achieve real equality in property rights? A case study of inheritance rights of women in Turkey, Women's Studies International Forum, Volume 69, No. 1, 2018;

Ni Luh Gede Isa Praresti Dangin, Kedudukan Hak Mewaris Wanita Hindu dalam Sistem Hukum Adat Waris di Bali, Kumpulan Jurnal Mahasiswa Fakultas Hukum, 2015. 